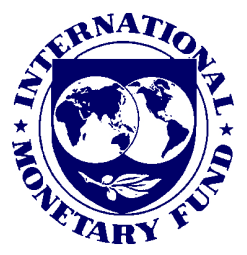

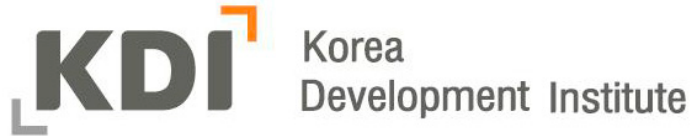

KDI/IMF Conference on Reconstructing the World Economy

February 25, 2010

Seoul, Korea

Session V

Future of the International Monetary System

\section{The Debate on the International Monetary System}

Presenter: Isabelle Mateos y Lago

Paper presented at the KDI/IMF Conference on Reconstructing the World Economy

Co-organized by the Korea Development Institute (KDI) and the International Monetary Fund (IMF), with the support of the Presidential Committee for the G-20 Summit,

Ministry of Strategy and Economy, Financial Services Commission, and Bank of Korea

Seoul, Korea- February 25, 2010

The views expressed in this paper are those of the author(s) only, and the presence of them, or of links to them, on the IMF website does not imply that the IMF, its Executive Board, or its management endorses or shares the views expressed in the paper. 
INTERNATIONAL MONETARY FUND

Strategy, Policy, and Review Department

The Debate on the International Monetary System

Prepared by Isabelle Mateos y Lago, Rupa Duttagupta, and Rishi Goyal ${ }^{1}$

Authorized for distribution by Reza Moghadam

November 11, 2009

DISCLAIMER: The views expressed herein are those of the author(s) and should not be attributed to the IMF, its Executive Board, or its management.

JEL Classification Numbers: F3, F31, F33

Keywords:

International monetary system; reserve currencies; country insurance; SDR; dollar; bancor; IMF imateosylago@imf.org; rduttagupta@imf.org;

Author's E-mail Address: $\quad$ rgoyal@imf.org

\footnotetext{
${ }^{1}$ The authors gratefully acknowledge the guidance from Ranjit Teja throughout the project, important contributions from Rodolphe Blavy, Padamja Khandelwal, and Chris Marsh, and inputs from Tam Bayoumi, Joannes Mongardini, Iva Petrova Krasteva, and Dustin Smith. They also thank Craig Beaumont, Carlo Cottarelli, Udaibir Das, Stanley Fischer, Atish Ghosh, Heikki Hatanpaa, Ioannis Halikias, David Hawley, Matthew Fisher, Nicole Laframboise, Kate Langdon, John Lipsky, Yinqiu Lu, Ousmene Mandeng, Reza Moghadam, Jonathan Ostry, Alvaro Piris, Narayanan Raman, Andrea Richter-Hume, Marco Rossi, Mahvash Qureshi, Sergio Rodriguez, and participants in the Global Economic Action Roundtable at the IMF 2009 Annual Meetings in Istanbul for many useful comments and suggestions.
} 


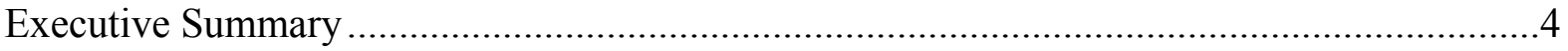

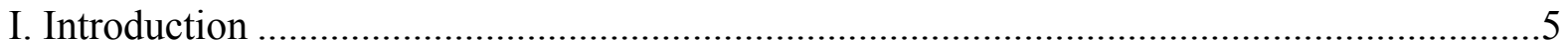

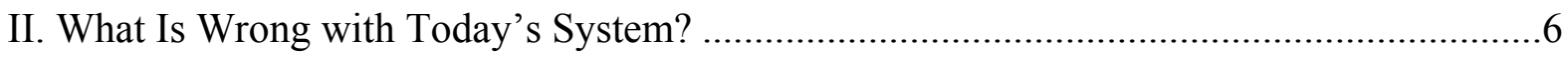

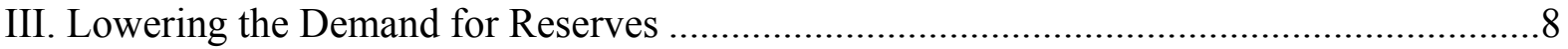

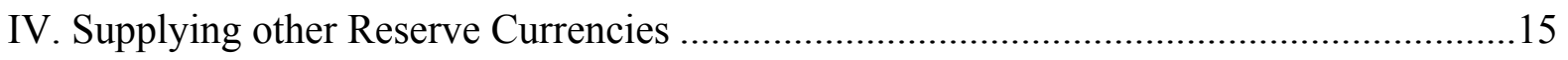

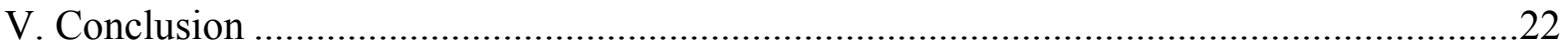

Figures

1. Evolution of International Reserves and Use of Dollars in the International

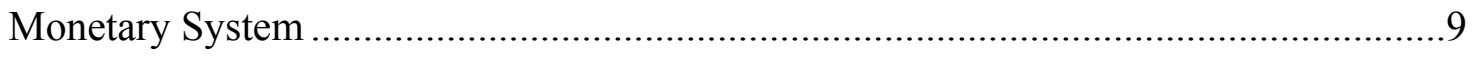

2. Features of Alternative International Monetary and Reserve Systems..............................23

Boxes

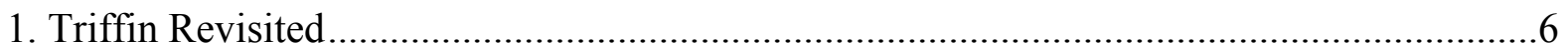

2. Should the IMF Provide Country Capital Insurance? .......................................................... 13

3. What Would It Take for New International Reserve Currencies to Emerge? .....................17

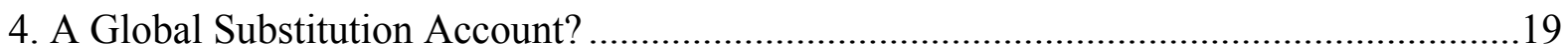

5. Keynes' Bancor and How It Might Work in Today's International Monetary System.......21

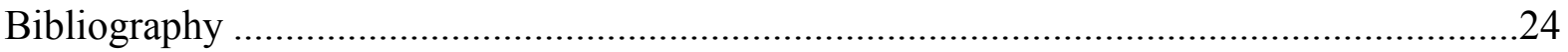




\section{EXECUTIVE SUMMARY}

The global crisis resurrected deep-rooted concerns about the functioning of the international monetary system (IMS). Despite its relative stability, the current "non-system" has the inherent weaknesses of a setup with a dominant country-issued reserve currency, wherein the reserve issuer runs fiscal and external deficits to meet growing world demand for reserve assets and where there is no ready mechanism forcing surplus or reserve-issuing countries to adjust. The problem has amplified in recent years in line with a sharp rise in the demand for reserves, reflecting in part emerging markets' tendency to self-insure against costly capital account crises. This paper considers options to address these tensions, thereby contributing to the ongoing debate on strengthening the international monetary system. On the demand side, it explores alternative insurance arrangements that could mitigate the precautionary demand for reserves. On the supply side, it assesses a menu of alternative reserve assets that could offer sustained stability and efficiency. Many of the proposals presented would require fundamental changes in the forms and degree of international cooperation, but may gain realism and practical relevance if more incremental efforts at strengthening the current system fail. 


\section{INTRODUCTION}

1. What "system"? The phrase "international monetary system" (IMS) refers to the rules and institutions for international payments. Less abstractly, it refers to the currency/monetary regimes of countries, the rules for intervention if an exchange rate is fixed or managed in some way, and the institutions that back those rules if there is a problem (through official credits, controls, or parity changes). With the world divided into a camp of major currencies that float freely and permit the free flow of capital, and another camp with varying degrees of control over exchange rates and cross-border flows, today's IMS is something of a "non-system." A key notion in this setup is that of reserve asset: so long as a country fixes or manages its exchange rate, it needs a liquid international asset of stable value to intervene with. Since the demise of real assets like gold as monetary anchors, the U.S. dollar has been the world's principal reserve asset. For the most part, that system has worked reasonably well - except when it has not.

2. What is the issue? In a nutshell, the concern brought to the fore by the crisis is the tension between (1) the scale and volatility of global capital flows, which motivates ever larger reserve buffers, and (2) questions about the desirability of anchoring the IMS on one country's currency (the U.S. dollar), given the origins of this crisis in the U.S. heart of the global financial system. As discussed below, these tensions are not new, and to some extent reprise the difficulties experienced by the previous - and also dollar-based - Bretton Woods Monetary System. The goal of this paper is to shed some light on the underlying tensions and touch on the reform proposals that have been floated.

3. Outline. In offering perspectives on tensions in the IMS and possible avenues for resolving these, this paper does not attempt definitive conclusions and remedies ${ }^{2}$ - not least because many of the ideas discussed require dramatic changes in the scale of global policy coordination, and amendments to the IMF's Articles of Agreement. Section II begins by outlining the problem with current arrangements for meeting the world's demand for reserve assets (e.g., the lack of adjustment by the reserve issuer and its "exorbitant" - if earnedprivilege of low-cost access to foreign capital). Section III asks how the demand side can be ameliorated by reducing incentives for reserve accumulation. Although some of the proposed remedies could be implemented quickly, they would only address part of the problem. Thus, section IV looks at the alternatives on the supply side, ranging from competing reserve currencies to multilateral assets like the SDR or a really new global currency. These remedies share a longer timeframe of implementation, but present difficult trade-offs in terms of stability, efficiency, sovereignty, and practicality. All this suggests that the current system, suitably strengthened, may endure for some time longer.

\footnotetext{
${ }^{2}$ In a complementary paper, Blanchard and Milesi-Ferretti (2009) discuss the risks from, and remedies for, large current account surpluses in some countries and deficits in others (global imbalances).
} 


\section{WHAT IS WRONG WITH TODAY's SYSTEM?}

4. Long-term structural concerns. In the midst of the world's worst economic and financial crisis in over 70 years, striking at the heart of the system, old worries have resurfaced about the inherent instability and unfairness of a system based on the currency of one country (see, for example, Zhou, 2009). All of these charges are open to debate, but the recurrence of concerns and phases of instability suggest a need to look for durable remedies.

5. Return of an old dilemma. Although many countries have moved off fixed exchange rates, the world as a whole has a growing appetite for reserves (see 910 ). Having this demand met predominantly by public asset issuance of one country makes it challenging, in practice, to achieve fiscal and external balance while providing an adequate amount of safe assets to the rest of the world. Key risks are deflationary bias if too few reserves are provided or accumulation of an unsustainable debt overhang if too many are (the "Triffin dilemma," which was originally developed in a world with few cross-border capital flows, but still lives today, albeit in a different form, see Box 1).

\section{Box 1. Triffin Revisited}

The Triffin dilemma was presented originally in a world of scarce capital flows, where the world's appetite for reserves was met through net asset issuance by the United States. With global capital flows, a single country that produces the global risk free asset could, in principle, provide a range of liquid assets to the rest of the world, while investing a similar gross amount in assets abroad and running a balanced current account:

- In some countries, reserves have been accumulated rapidly in the face of strong capital inflows in recent years, not sustained current account imbalances. But for the world as a whole, given central banks' revealed preference for public sector liabilities, external balance would require that, in the reserve issuer, either the public sector accumulates foreign assets to balance foreign purchases ${ }^{1 /}$ or the private sector offsets public sector dissaving through increased net saving.

- In practice, demand for reserves is likely to lower real interest rates in the reserve issuer below the level that would prevail in the absence of global capital flows (the "autarkic" rate), thereby providing incentives to dissave for both the public and private sectors.

- Should the reserve issuer's public sector be unwilling to accommodate the foreign demand, alternative reserve assets (such as agency paper) could arise that may not be of the same quality or usability during stress periods. This "debasement" is the modern equivalent of the deflationary bias and further contributes to systemic instability.

Thus, a contemporary version of the Triffin dilemma is likely to assert itself, wherein growing demand for safe (Treasury) assets would lead to indebtedness, which in time could undermine the confidence that is the basis for its reserve asset status.

\footnotetext{
${ }^{1 /}$ The public sector could also purchase domestic assets while the private sector purchases foreign assets.
} 
6. Exorbitant privilege? The reliance on one country as a key supplier of global reserve assets gives that country a unique advantage - some call it an "exorbitant privilege"-in running its policies. This is because this center country has more macroeconomic policy space by virtue of the greater liquidity of its markets and ability to borrow in its own currency abroad at lower cost, as well as the seignorage earned from issuing a global currency (distinct from, but associated with, its role as a reserve asset). For example, the ability to borrow in its own currency gives the reserve issuer a capital gain when its currency depreciates vis-à-vis its financial partners - with U.S. assets being mainly foreign currency denominated and U.S. liabilities almost entirely dollar denominated, the United States enjoyed a net capital gain from the gradual dollar depreciation for several years in the run up to the crisis of over $\$ 1$ trillion (see Clarida, 2009, for a recent estimate in a long body of work). That said, while in the early decades of the Bretton Woods system the dollar's primacy was rooted in law, this has not been the case for the past 30 years: dollar reserves have been accumulated as a matter of choice and the track record of U.S. policies over decades has, in the main, helped preserve macroeconomic and financial stability. Its open capital account and deep financial markets have contributed to growth in global trade in goods and assets, as scale economies in the use of the dollar have materialized. In that sense, the relative return on assets could be seen as payment for world banking services, and what privilege the dollar enjoys is an earned one.

7. Asymmetric adjustment. This "privilege" reflects also an asymmetry in adjustment to shocks, with much greater pressure on (nonreserve) deficit countries to adjust than surplus or reserve-issuing deficit countries. Thus, persistent surpluses create a demand for financial instruments that the center country (and it only) can easily meet, a combination that accommodates the buildup of global imbalances.

8. Anchoring the center. Another uncomfortable implication of a system giving primacy to one country's currency is that the world is in a sense hostage to the reserve issuer's ability to preserve its currency's value. This in itself is a source of uncertainty as evident in recent concerns about the U.S. dollar. An obvious solution is for the center country to adopt policy frameworks that durably alleviate such concerns: strengthen financial regulation, keep public finances on a sustainable path, and lower incentives to inflate away any debt overhang by ensuring central bank independence, issuing inflation-indexed instruments, and adopting a credible fiscal responsibility framework. In principle, contestability should provide reserve issuers with an incentive to implement such policy frameworks, though an imperfect one in the absence of credible challengers. In addition, IMF surveillance could be a multilateral mechanism to foster discipline. However, deprived of an enforcement mechanism, surveillance alone has historically been a weak anchor. The mutual assessment process assisted by IMF surveillance that the G-20 leaders agreed on at their Pittsburgh Summit in September 2009 could help give it more traction.

9. Large reserve holdings. Finally, large official holdings of reserves distort global capital flows towards the center, reducing the benefits of capital account liberalization. They 
also breed market uncertainty, which may be particularly destabilizing when, like now, holdings are highly concentrated. The exceptional volume and concentration of dollar reserve holdings by the official sector (Figure 1) provide some support for the current system in normal times, for instance, to be able to counteract — with some multilateral coordinationpotentially destabilizing market movements. But they can heighten risks in periods of uncertainty, as it has been argued their management may reflect nonmarket considerations.

\section{LOWERING THE DEMAND FOR RESERVES}

10. Key drivers. Despite the movement toward floating since the 1970s, the global stock of reserves has kept rising relative to key benchmarks, owing in large measure to emerging markets, and these reserves have been accumulated across exchange rate regimes (Figure 1). So moving away from fixed exchange rate regimes need not imply a diminution in reserve accumulation in the presence of other motives for holding reserves.

- $\quad$ Emerging markets' holdings reflect in some cases an end in themselves: to buffer the scale of exchange rate adjustments in the face of shocks - traditional terms of trade ones but also shocks from hot money inflows in good times that turn to sudden stops in bad ones; to accumulate liquidity as a backstop for a potential banking crisis; and to boost policy credibility. According to some estimates, insurance motives account for about two thirds of current reserve holdings, or $\$ 4$ to $\$ 4 \frac{1}{2}$ trillion, and over half of the increase over the past decade (drawing on Obstfeld, Shambaugh, and Taylor, 2009).

- In a few other cases, reserve holdings are a byproduct of efforts to limit nominal exchange rate appreciation either out of concern for its impact on growth or as part of the monetary policy framework (the latter reflecting structural factors). For instance, commentators generally agree that, in cases such as oil exporters and China in recent years, reserve accumulation far exceeds conceivable precautionary needs, and reflects, respectively, the desire to boost public savings to ensure intergenerational equity in the context of eventual depletion of oil reserves, and the counterpart to an export-led growth strategy (see, for example, Subramanian, 2009).

- Different motivations require different responses. We focus here on lowering the precautionary demand. Other forms of demand for reserve assets may be more realistically mitigated by measures targeted at avoiding the unbound accumulation of current account surpluses, and providing opportunities for diversification (see Section IV) or for investments in less liquid assets, e.g., via sovereign wealth funds. 


\section{Figure 1: Evolution of International Reserves and Use of Dollars in the International Monetary System}

The stock of international reserves has increased rapidly in recent years, by more than key macro-financial variables, especially for emerging markets.
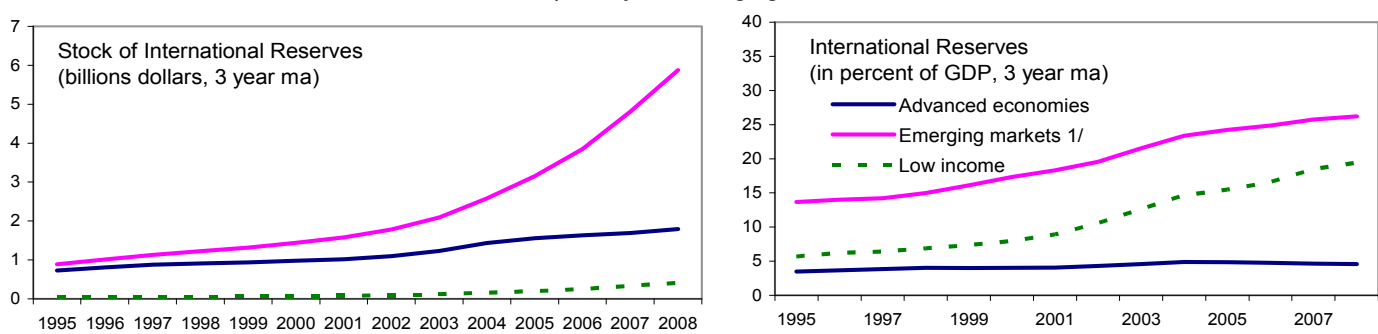

19951996199719981999200020012002200320042005200620072008

angement exists, a handful of countries account for more Although no obvious reserve pattern by de facto exchange rate arrangement exis than half of total reserve holdings.
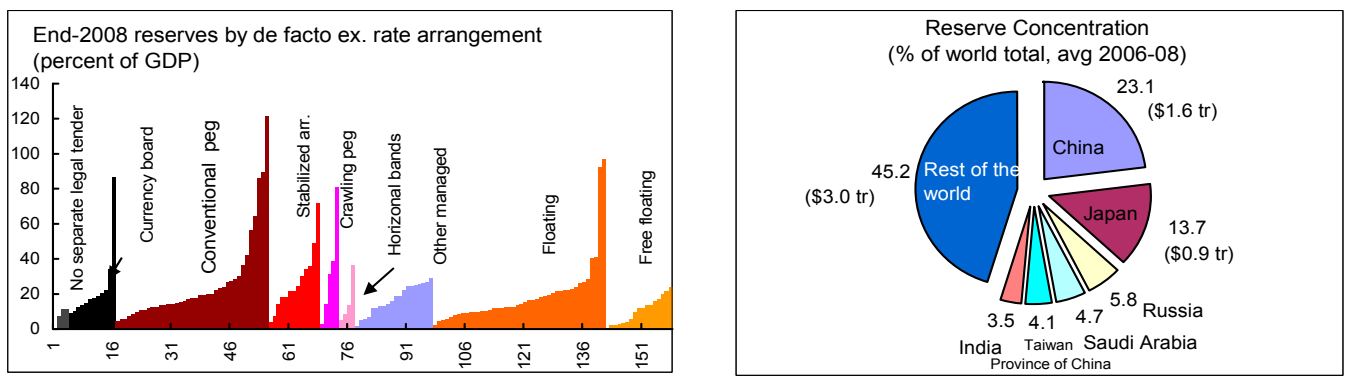

Meanwhile, despite the United States being the global crisis epicenter, liquid dollar assets were a safe haven; and the dollar share in reserves has remained high.

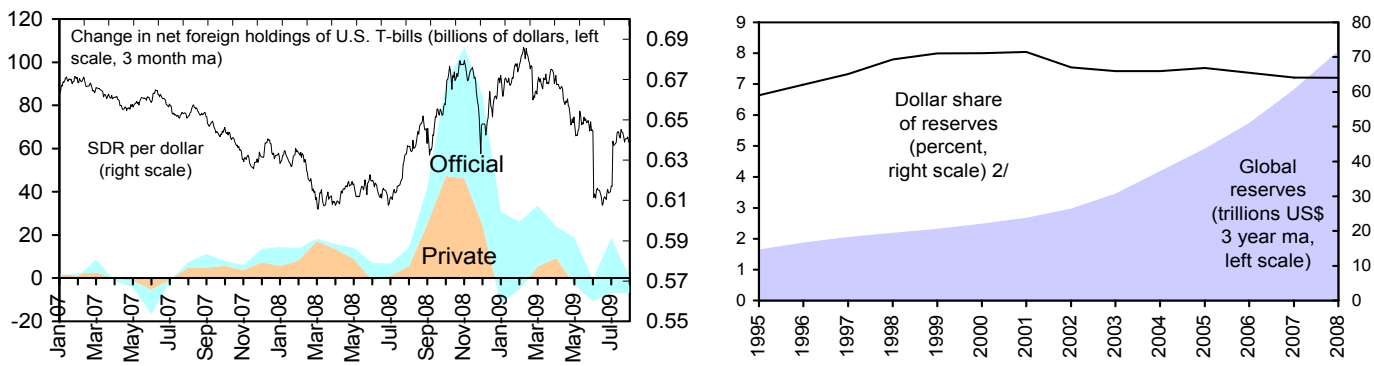

The dollar still dominates foreign exchange transactions, and most countries settle a larger proportion of their external trade with dollars than their actual trade with the United States.
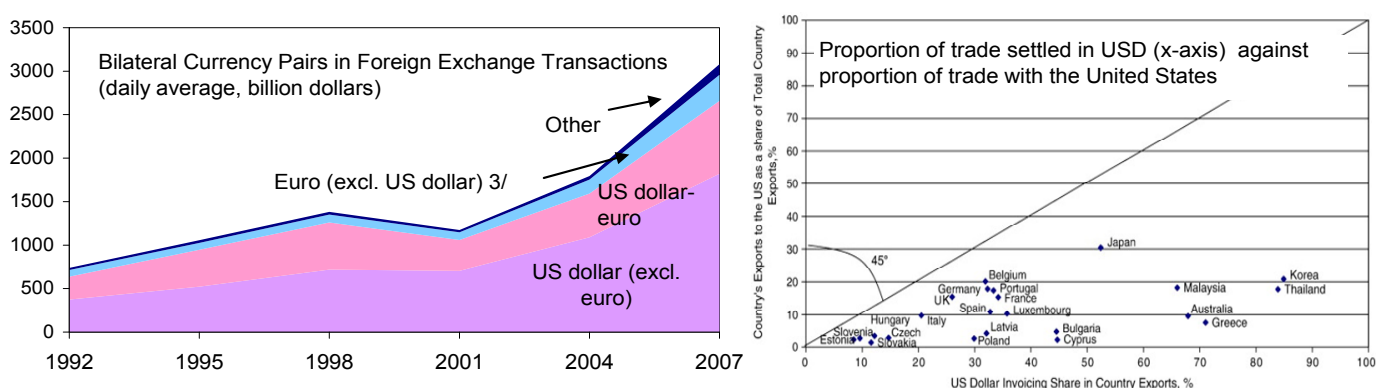

Sources: AREAER, BIS, COFER, Goldberg and Tille (2008), IFS, TIC, and WEO.

1/ Compared to standard WEO classification, Hong Kong SAR, Korea, Singapore, and Taiwan Province of China have been moved from ADV to EM.

2/ Reports the dollar share of "allocated reserves" in COFER data. This is therefore the share of reserves that have been assigned a currency denomination. "Unallocated reserves" have been growing as share of total in recent years, from 25.6 percent in 1995 to 37.1 percent in 2008.

3/ Before 1999, Deutschemark trades (excluding against other EMU currencies) shown. 
11. Alternatives to self-insurance. The relative stability of countries holding large reserves over the crisis has confirmed for many emerging markets the desirability of largescale insurance. However, self-insurance is a costly, globally inefficient way of meeting the need. Over time, this need would be expected to decline as the "core" of the system expands to include more emerging markets that have a track record of policy credibility and that allow automatic adjustments of their exchange rates (i.e., moving to truly floating exchange rate regimes) while holding minimal reserves, similar to most advanced economies. Adoption at the national and global levels of prudential and regulatory measures that limit the scope for capital flows to disrupt financial systems would help too, as would stronger surveillance over global financial stability. Meanwhile, the alternatives to self-insurance include:

- $\quad$ Third-party insurance, in theory, is the most efficient response, but also difficult to implement given market failures at many levels: the absence of liquid markets, significant upfront costs to underwriters for identifying risks and returns adequately (creating a first mover's disadvantage), difficulty in pricing tail events such as financial crises, moral hazard, adverse selection, and counterparty risks, including the inability to diversify sovereign risks. Even if these market failures were addressed, insurance would probably be limited to small- or medium-sized sovereign clients.

- Borrowing from a global or regional reserves pool or through access to a global lender of last resort (i.e., able to deploy its resources rapidly in a crisis), provided these are viewed as credible and less costly alternatives to self-insurance (see below).

12. The IMF's role. The IMF, given its global membership and crisis prevention and resolution mandates, has a central role to play in fostering and offering such alternatives. In fact, the Fund already fulfills this role to some extent, but the effectiveness of its instruments is arguably hampered by concerns about governance and stigma. Moreover, on-demand financing will need to be sufficient to offset a sudden stop or stem a bank run. The current crisis has also rekindled the possibility that advanced countries may need external financing, like in the Fund's early days, and Fund resources would need to be bolstered significantly to play any meaningful role in potentially financing all but the smallest advanced countries. In addition to the IMF, other insurance arrangements, such as regional pools and bilateral swaps, would be useful complements, although with more limited scale, scope for risk sharing, and surveillance arrangements.

\section{Access to Precautionary Resources}

13. Beyond existing credit lines. With the creation of the Flexible Credit Line (FCL) and mainstreaming of high-access precautionary arrangements (HAPA), the Fund has added sensible contingent credit line instruments to its toolkit. But not all countries qualify, nor can they have assurance that they will qualify when money is needed — an issue exacerbated by perceptions of lack of fairness of the Fund's governance structure. Thus, the existence of these instruments cannot be seen as a direct substitute for reserves. The predictability and 
reliability of access to the FCL could be enhanced with an objective qualification process to determine which member countries qualify for access (see Ostry and Zettelmeyer, 2005). While this would not ensure access to all members, it would enhance predictability as to whether additional resources (when needed) are available, and in what range. As a side benefit, the process could act as an incentive for countries to build a track record of good policies. A trade-off to consider in designing the process is that qualification decisions might need to be kept confidential, to avoid destabilizing nonqualifying countries. At the same time, if not made public, the availability of the instrument would not have the same impact on market confidence as actual reserve buffers.

\section{Increasing access to unconditional resources:}

- $\quad$ A pure liquidity line. This could be achieved by establishing an overdraft facility similar to those enjoyed up to a limit by commercial banks with central banks. Access rights could be set in proportion to members' quotas, or linked to another indicator of capacity to repay. The first credit tranche policy provides a good model (currently at 25 percent of quota, and available effectively without conditionality), though the size of this facility would need to be substantially larger (e.g., 100 percent of quota subject to debt sustainability checks). The impact would be all the greater if combined with a quota increase.

- $\quad$ Contingent general SDR allocations. Instead of depending upon ad hoc allocations requiring an 85 percent majority of the IMF's Governors, SDRs could be generated automatically at a predetermined pace, but allocated only in case of systemic crises, with the latter predefined on the basis of global economic and financial conditions. The key would be in ensuring that these resources are used to deal with crises but do not become a permanent transfer, for example, by reinstating a reconstitution requirement whereby countries would need to rebuild their SDR holdings up to a minimum share of their cumulative SDR allocations over a certain time horizon.

- $\quad$ Supporting insurance markets. The Fund could play a role to help develop insurance markets against exogenous shocks, or encourage countries to make greater use of private sector hedging instruments by offering technical support. It could also use its surveillance to inform insurers (along with the broader public) on the risk profile of potential clients (Box 2).

$>$ Moral hazard could be addressed by restricting the insurance payout to crises that are not caused by domestic policies, while linking the availability and cost of safety net instruments to IMF surveillance assessments would strengthen countries' incentives to adopt good policies. Instruments could be made contingent on country exposures to specific global conditions such as commodity prices (for commodity exporters), or the VIX index, to serve as hedging instruments, with premia rising with the risk profile. Admittedly, it would be 
possible to design purely exogenous triggers only for those countries whose economies are small relative to the world economy and whose actions do not affect global conditions. The use of clear preconditions as triggers for payouts (tied to global indexes) is also key to ensure that insurers have no scope for reneging on their contracts.

Greater Fund involvement in coordinating or even providing insurance (see Eichengreen, 2009; Cohen and Portes, 2006; Cordella and Levy-Yeyati, 2006) raises several issues, however-for instance, balance sheet impact of systemic events, possible conflict of interest issues for its surveillance assessments, or inducing irresponsible behavior for other insurers (see Box 2) - suggesting that the Fund's role should probably be limited to supporting insurance or at best as a temporary market maker.

The near impossibility of designing an insurance instrument against systemic shocks does not imply that country insurance against any capital account crisis is doomed to failure. Insuring against country-specific external risks-such as sudden stops triggered by slumps in commodity prices for commodity exporterswould seem both feasible and useful.

With respect to systemic events too, the Fund could play a very important role in providing a backstop to a potential global liquidity squeeze (see below).

15. A dependable governance structure. Emerging markets' less-than-full confidence in Fund financing might also reflect concerns about the Fund's governance structure. These concerns could be addressed by appropriate rebalancing of IMF quotas and management/staff diversity, which would increase the confidence of many members that decisions are fair. Alternatively, to ensure that there is no conflict of interest between Fund lending and its assessment of country policies to qualify for loans, qualification decisions could be madeor at least reviewed - by a politically independent body of technocrats with incontrovertible analytical credentials (along the lines suggested for early warnings by Stern, 2009). However, forming such a politically acceptable group to take these qualification decisions, and ensuring the group is effectively insulated from pressures, would be a tall order. 


\section{Box 2. Should the IMF Provide Country Capital Insurance?}

Insurance provided by the private sector against sudden stops has not been extended to sovereigns spontaneously. Private contingent credit lines extended to the sovereign are limited; options on the VIX or EMBI or CDS spread are rare, while a strategy aimed at obtaining a significant payoff in the event of large declines in the S\&P500 is likely to be very expensive. The global catastrophe reinsurance market is mainly within advanced economies. GDP-indexed bonds are rarely used and generally are not tradable.

This limited range largely reflects market failures (discussed in 911 ). Thus, a global institution like the IMF (or any other international financial institution) could seek to generate the needed economies of scale for reducing underwriting costs, while pooling country-specific risks in a diversified portfolio to substantially reduce pricing. An advantage over existing facilities is that such an instrument could be available to the entire membership, with the strength of countries' fundamentals and policies reflected in their risk premia rather than in qualification or nonqualification. However, several issues need to be considered to assess the appropriateness of the Fund in providing insurance:

- $\quad$ Pricing systemic risks: The recent crisis has revealed how cross-country linkages can trigger a global crisis. While the Fund may be in a better position to identify systemic risks than private insurers, even so, pricing rare systemic events would be challenging.

- $\quad$ Balance sheet effects on the Fund: Related to the above, risks of a near-global shock with simultaneous payouts need to be recognized, and premia would need to be invested appropriately to build a cushion for substantial payouts. If the Fund were the insurer, this facility should draw on a separate pool of resources than its General Resources Account to eliminate the risk of a large payout affecting the Fund's ability to finance its standard lending facilities.

- $\quad$ Role of surveillance: The Fund's surveillance assessments, used to determine risk premia insurance, would get more traction, limiting adverse selection and moral hazard. Access to superior and timely information as a market maker would also help safeguard the system and facilitate backstop provision in the event of a liquidity squeeze (see below). However, there could be a potential conflict of interest between the role of conducting unbiased surveillance on the one hand, while retaining an insured clientele on the other (similar to the issues discussed in 913). The use of very objective and automatic qualification criteria may minimize the scope for such a conflict.

- $\quad$ Reverse moral hazard: Private insurers, knowing that insurance provided to countries backed by the Fund are relatively safe, could be induced to take more risks in other investments.

To minimize concerns associated with systemic risks, one option would be to design an insurance instrument that excludes global shocks - while limited in scope, such a facility could still insure countries against idiosyncratic shocks (such as commodity price slumps for commodity exporters) as long as they do not become systemic events. Also, clear and automatic criteria would need to be used for suspending payouts under global crises. In the latter event, the Fund's role as a liquidity provider would be key (see 1 16). To address the remaining issues - such as a potential conflict of interest for surveillance - the Fund's market making role can be temporary, allowing it to exit once the market is sufficiently deep. In this phase, the Fund could continue to encourage countries to make greater use of available private sector insurance through its surveillance assessments, estimation of risk premia associated with alternative tail events, and by promoting adherence to data dissemination standards that allow a more reliable identification of vulnerabilities. 


\section{A Larger Pool of Resources-Some Considerations}

16. The needed resource base. To provide meaningful comfort, the Fund would require a much greater resource base, which grows in line with precautionary needs. Academic assessments of the minimum resources that the Fund would need range from $\$ 1$ trillion (Johnson, 2008), to an unlimited amount implied by Calvo's (2009) call for the Fund as a lender of last resort. A rough estimate of precautionary reserves currently held is around $\$ 4$ to $\$ 4.5$ trillion ( 10 ), six times the Fund's lending capacity after the agreed tripling from pre-crisis levels. A greater and more dynamic lending capacity could be achieved directly from members (all or a subset) or by issuing SDRs:

- Indexed quotas. As a quota-based institution, the most natural way for the Fund to expand its resource base would be to expand its quotas and keep them growing in line with benchmarks of the size and perhaps volatility of the global economy (e.g., GDP, capital flows). A simple indexation mechanism would be ideal but may not be realistic in light of many members' budgetary frameworks, which may not allow them to make such an open-ended forward commitment of resources. But a treatybased presumption of indexation could go a long way.

- $\quad$ A reserve pool. In addition, willing members might decide to pool part of their reserves, e.g., in a trust fund, offering control over the use of resources proportional to their contributions. Such a pool could directly supplement the Fund's own resources in the way the New Arrangements to Borrow (NAB) currently does (i.e., providing additional financing for facilities supported by the Fund's general resources); or it could provide financing for alternative facilities that may not be supported by the membership as a whole (e.g., because they are perceived by some creditors as too risky), thereby offering a further solution to the governance problem identified above (as contributors could have a predominant say in how the resources are used). Of course, this latter form of reserve pool could be established by members independently of the Fund, but relying on the Fund to manage it would offer both convenience and efficiency benefits.

- $\quad$ New SDRs. Currently, SDRs are created when there is a long-term global need to supplement existing reserves, and allocated unconditionally to members based on their quotas. Reforms could be implemented to allow for SDRs to be created and temporarily allocated to specific members to finance the Fund's various credit lines, allowing the Fund to respond to any crisis with limited or no resource constraints. At the same time, there would be clear predetermined criteria to cancel the SDRs once the crisis had passed and the Fund had been repaid (see Cooper, 2009). This type of mechanism would also help in responding effectively as a preprogrammed "lender of last resort" during periods of intense global liquidity demand. As SDRs are claims on stronger members' reserves, this would be conceptually analogous to a contingent reserve pool involving all members with strong enough balance of payments. 


\section{Other Incentives}

17. Dampening appetite for reserve hoarding. Another way to reduce the demand for reserves would be a charge to cover the potential instability in the international system caused by such behavior. This could be implemented by a remunerated reserve ratio above certain thresholds, with the proceeds used to bolster the global reserve pools for emergency lending discussed above. Countries subject to the reserve requirement would be remunerated at the market SDR rate and would thus not face an incentive to reduce their own reserves; however, the availability of these resources to meet the liquidity needs of others would contribute to reducing their demand for reserves. Stronger direct incentives could be envisioned; for example, Eichengreen (2009) moots a tax on persistent current account surpluses. Such asymmetric penalties seem unlikely to find global support, however, unless most countries found themselves with broadly balanced external positions or no excess reserves. To garner support, such measures could be announced with a long enough transition period prior to implementation and only after superior alternatives to self-insurance have been secured.

\section{SUPPLYING OTHER RESERVE CURRENCIES}

18. Alternatives. As the solutions reviewed above to attenuate the demand for reserves would at best address only a part of the problem, it is worth looking into alternative reserve currency systems that could be envisaged in place of the current dollar-based one: multiple or competing reserve currencies with no dominant one; an SDR-based system that pools the main reserve currencies; and a bancor-style global reserve currency that circulates along with other currencies. Each system has its pros and cons and needs to be assessed against several criteria among which trade-offs are inevitable. Here we focus on the following: stability, efficiency, political feasibility, ease of implementation, and fairness (Figure 2 provides a summary assessment). The preferred system will depend on the premium placed on the different objectives and whether the net gains justify the effort to overcome the practical obstacles involved. Also, different systems have different winners and losers compared to the current one, which raises an additional hurdle in finding global agreement on something else than the status quo. Of course, none of these new systems would come about by legislation. But all would require a synchronous change in the behavior of the world's major central banks, as well as varying degrees of coordination among governments.

\section{Competing Reserve Currencies}

19. A multiple-currency system. Although there are few precedents, it is possible that several broadly substitutable reserve currencies could emerge over time - the main difference with today's system being the absence of a clearly dominant one. The prospect of competing on a par with the dollar as a global reserve asset is a possibility for economies with financial systems, international trade, and GDP that are comparable in size to those of the United States, and backed by policy-making institutions with similar credibility. The Euro, first, the 
yen and the Chinese RMB, later, may find themselves in that position in the future, if the respective authorities are willing to take the steps needed for such a development to occur (see Box 3). A question is whether even fully substitutable currencies could overcome the network externalities that strongly push all actors to converge to a dominant currencyhistorically, bi-currency systems such as gold/silver in the nineteenth century and sterling/dollar following WWII, have tended to converge to a mono- (or dominant-) currency one, and although transactions costs have declined greatly, there is evidence that these network externalities are alive and well (e.g., Meissner and Oomes, 2008).

20. Key properties. Such a system would impose policy discipline on reserve issuers, as concerns about the value of one currency could lead to a shift towards the others. The "exorbitant privilege" currently enjoyed by the United States would be spread across a few more countries' currency areas. But overcoming network thresholds and coordinating an orderly shift away from the dollar as the dominant reserve currency will be challenging. If network thresholds could be overcome, the efficiency that results from scale economies would be sacrificed in part, though that may be an acceptable price to pay for greater systemic stability. At the same time, competing stores of value could lead to higher exchange rate volatility if reserve asset holders manage their portfolios actively (see United Nations, 2009). Close policy coordination among key reserve issuers would be necessary to keep such exchange rate volatility at bay. But instability risks would also be lower in a world where demand for precautionary reserves had been tamed so that the bulk was held for transactions purposes, attenuating the need for active portfolio management. 


\section{Box 3. What Would It Take for New International Reserve Currencies to Emerge?}

New international reserve currencies may emerge in the future, but for this, a number of developments will be required. In the near term, given the dominance of the U.S. dollar in private transactions and financial markets, few candidates could replace it. The euro, the yen, the renminbi, and possibly other currencies may take on a greater global role in the future, as the following reconditions are increasingly met:

- Deep and liquid financial and foreign exchange markets that remain resilient during crises. Prerequisites for developed financial markets include an open capital account and currency convertibility. ${ }^{1 /}$ Financial market infrastructure is also important.

Current situation: The U.S. financial markets are the most deep and liquid, followed by the euro area; the United Kingdom and Japan are less so. These differences were especially evident when, at the height of the recent crisis, liquidity evaporated in all markets except the United States. Lower depth and liquidity reflects structural issues as well as restrictions. For example, fragmentation and lower credit quality in sovereign offerings is believed to hamper financial market development in the euro area. Similarly, a withholding tax on interest is believed to hinder foreign participation and deepening of government securities markets in Japan. Lack of convertibility and capital account restrictions have led to relatively underdeveloped financial markets in China.

- Macroeconomic stability to ensure confidence in a currency's long-term purchasing power. Policy-making institutions with credibility and a track record of maintaining price stability are a critical ingredient. Whether this would also entail moving to a market determined exchange rate regime remains an open question.

Current situation: While current reserve currency issuers (Euro area, Japan, the United Kingdom, and the United States) have had track records of broadly comparable strength, the crisis has raised fiscal sustainability concerns, requiring credible exit strategies to avoid undermining their reserve issuer status. China's adoption of conservative fiscal and monetary policies in the context of a pegged exchange rate and capital controls has so far helped maintain a relatively low inflation environment and resilience to external shocks, and key would be to preserve macroeconomic stability over the medium term even as the economy undergoes fundamental structural changes.

- Wide use in private sector transactions. A currency with a large share in world GDP, trade, and finance attracts more users as other countries use it for trade, as a monetary anchor, as well as to conduct financial transactions. This attracts network externalities through a self-reinforcing cycle of lower transaction costs and higher liquidity.

Current situation: BIS data from 2005 indicate that the U.S. dollar was involved in about 90 percent, and the euro in almost 40 percent, of all foreign exchange transactions. Other currencies were less prominent. Going forward, regional reserve currencies that meet the other conditions and dominate regional trade could provide a substantial domestic store of value and diversification benefits.

The emergence of a new international reserve currency may also require overcoming reluctance on the part of reserve issuers. Reserve currency status presents challenges in macroeconomic management for the issuer. These challenges include the inability of the issuer to actively use exchange rates as a macroeconomic adjustment tool, volatility of short-term capital flows, and the implications for fiscal policy of the need to achieve greater depth in government securities' markets.

\footnotetext{
${ }^{1 /}$ A number of convertible currencies (e.g., Swiss franc, Australian dollar, Swedish krona) are eligible reserve assets, but are not used globally.
} 


\section{An SDR-Based System}

21. SDR resurrected. The SDR - which is a claim on a basket of currencies but not a currency itself - is enjoying a renaissance after falling into near oblivion for decades. Recently, both demand (from BRIC central banks) and supply of SDR assets (from the Fund) have materialized, though on a limited scale - about 4 percent of global reserves. If promoted to gradually become the principal reserve asset in the system (as in fact envisaged by the IMF's Articles of Agreement), it could allow for a shift away from a dollar-centric system while maintaining the network externalities that favor a single currency-anchored IMS. By being available as a composite product, the SDR also offers a convenient means of reserve diversification and stable store of value. For the SDR to take on a significant role, however, its liquidity would need to increase massively. To this end, in addition to greater issuance by the Fund and efforts to enhance the liquidity of the SDR market, key players would need to encourage and subsidize the development of a private SDR market, e.g., with Treasuries and private borrowers issuing SDR-denominated debt (though settled in one of the component currencies), and perhaps some major countries pegging to and invoicing in it. If embraced by enough actors, liquidity could grow relatively rapidly. Such a system would have the following properties:

- Stability. An SDR-based system inherits many of the positives associated with a multiple reserve currency system. It provides instant diversification benefits by pooling together the main reserve currencies; therefore, it is a more stable store of value and unit of account compared to its component currencies taken separately (and is also greatly more convenient than managing an equivalent portfolio of the component currencies). Being a derivative product, whether an SDR-denominated reserve asset would be a good store of value would still very much depend on the stability of the component currencies. However, as the weights of different currencies in the SDR basket are defined in "hard" terms (e.g., 44 U.S. dollar cents per SDR), relative weights adjust automatically on the basis of exchange rate movements, providing a policy disciplining mechanism on reserve issuers (as a country issuing too much would see its exchange rate depreciate and therefore so would its weight in the SDR basket).

- Balance. An SDR-based system would spread the "exorbitant privilege" across the countries whose currencies make up the SDR basket, and this privilege-spreading could be achieved faster and more broadly than in the multiple reserve currency system discussed previously, where economies of scale remained an important consideration. Moreover, SDRs issued by the Fund, if targeted to emerging markets and developing countries in sufficient volume to make up a significant share of their reserves over time, would reduce the need for them to export capital to reserve issuing countries, as SDRs replicate the "hard" currency properties of the underlying components without the need to hold them (as suggested by Clark and Polak, 2004). Adopting a rule requiring countries to reconstitute their holdings of SDRs over a certain horizon after spending them might 
be necessary to prevent such SDR allocations from being a pure transfer of resources and make sure they actually boost reserves.

- Coordination requirements. The steps required to move to an SDR-based system would be ground breaking, requiring considerable appetite for global policy coordination, including from the United States, whose reserve asset the SDR would replace. That it could be mobilized and sustained seems doubtful unless the system - whether the current one or another it morphed into-fails in a major way. A somewhat less ambitious alternative would be to make the SDR one of the alternative reserve currencies in a multicurrency system as described above.

22. Substitution account. Should a shift to an SDR-based system be deemed desirable, a global substitution account, as envisaged in the 1970s, could speed up the transition if support for it could be mobilized. However, it may not be in the interest of the broader membership as it would socialize costs of adjusting a few large balance sheet positions concentrated in the dominant currency (Box 4). That said, to the extent demand for SDRdenominated reserve assets grows faster than the supply of U.S.-issued reserve assets shrinks, the process could lead to an increase in U.S. interest rates, with implications for the interest rate differential with other major currencies and bilateral exchange rates. The pace of transition would therefore warrant careful consideration.

\section{Box 4. A Global Substitution Account?}

The crisis has revived interest in a global off-market mechanism for reserve holders to convert their excess reserves into SDR-denominated assets. Operated transparently and with clear rules, it could alleviate concerns of a disorderly diversification out of dollars by the largest reserve holders. If the account holds a large share of its assets in dollars, it would bolster confidence in the current reserve asset in the near term, by taking potential overhang off the market. If a gradual shift to a system based on alternatives to the dollar were deemed desirable, or inevitable, asset allocation rules could be put in place stipulating a gradual rebalancing of the portfolio (see Fred Bergsten's “We should listen to Beijing's currency idea", April 8, 2009).

The idea is not new. Similar plans were devised in the late 1970s, when concerns about the dollar's valuelike now-were running high. It involved having the Fund set up a so-called substitution (or reserve diversification) account, which would have allowed central banks to swap dollar assets (typically, short-term U.S. T-bills) for SDRs. The Fund would in turn convert the U.S. T-bills for longer-term claims on the U.S. Treasury, with the spread between the long-term interest rate and the short-term rate paid to SDR holders helping to cover the exchange rate risk. In fact, however, there was no assurance that the exchange rate risk would be covered (e.g.. the shift in relative demand could flatten the yield curve and reduce the term premium). Other mechanisms for sharing the exchange rate risk were floated, such as investing in government bonds of the SDR component currencies (16 at the time) or using a portion of the Fund's gold stock to absorb the costs. But the scheme never came into force as members could not agree over cost sharing of these risks, presumably reflecting in the end a fairly sanguine view of the dollar's prospects, which turned out to be warranted.

Today's circumstances seem rather similar, and making the substitution account a reality would require agreement on socializing the exchange rate risk that is currently concentrated in certain large balance sheet positions. Indeed, some have argued that Governor Zhou's proposal to substitute the SDR for the dollar is a way for the Chinese central bank to diversify reserves swiftly out of dollars without facing capital losses. Ironically, the status quo may offer better incentives toward orderly diversification, as the high costs of moving out of dollar assets too fast make such a move unlikely. 


\section{A Global Reserve Asset and Currency}

23. Keynes revisited. A radical redesign of the international monetary system would be to introduce a new currency (Box 5) — an "outside" money — that could be used in international transactions and would float alongside national currencies. ${ }^{3}$ The currency would be issued by an international monetary institution with a governance structure quite different from today's IMF and geared towards ensuring a stable value. Disconnected from the economic problems of any individual country and with a balance sheet backed by the membership of the institution, this currency could serve as the global risk free asset. Scale economies in its use could deliver efficiency in international transactions, and the "exorbitant privilege" enjoyed by other major reserve issuers would be transferred to the institution's membership. Therefore, adjustment would become less asymmetric, as surplus countries that peg their exchange rates to this currency would see their currencies appreciate relative to deficit countries that float, enhancing systemic stability. Such an institution could also serve as a true global lender of last resort that could attenuate deflationary bias and resolve funding issues associated with multilateral bailouts or lines of credit. However, a solution of this nature seems so impossibly taxing of national sovereignty that it would be tempting to dismiss it as utopian. Yet, a monetary institution with even more demanding features - the ECB - is celebrating its 11th anniversary this year. If an SDR-based system were to emerge at some stage, taking the next step to a sui generis global currency may seem less of a giant leap than from today's vantage point.

\footnotetext{
${ }^{3}$ An extreme version would be to have a global currency that would serve as domestic currency for the countries that wish to do so.
} 


\section{Box 5. Keynes' Bancor and How It Might Work in Today's International Monetary System}

Keynes' original proposal envisaged a global bank (the International Clearing Union or ICU), which would issue its own currency (bancor), based on the value of 30 representative commodities including gold, exchangeable against national currencies at fixed rates. All trade accounts would be measured in bancor, while each country would maintain a bancor account vis-à-vis the ICU (expected to be balanced within a small margin), and also have an overdraft allowance vis-à-vis the ICU. When countries experienced large trade deficits (more than half of the bancor overdraft allowance), they would pay interest on their accounts, undergo economic adjustments (possibly also capital controls) and devalue their currencies. Conversely, countries with large trade surpluses would also be subject to a similar charge and required to appreciate their exchange rates. This mechanism would bring in a smooth symmetry of adjustments across countries and avoid global imbalances.

The global reserve currency (GRC) conceived here would, akin to Keynes's bancor, be accepted as international legal tender by the member countries of the international monetary institution (IMI) that backs it, with the latter being the sole issuer of the currency (unlike Keynes's bancor, GRC would not be commodity based, however). While member countries would not issue the GRC, they could issue financial instruments such as bonds denominated in it, and choose how the value of their currencies visà-vis the GRC would be determined. The balance sheet of IMI would need to be impeccable ("AAAA") to ensure full credibility in the international community (including the private sector), given that the latter would be allowed to hold GRC and GRC denominated bonds. ${ }^{1 /}$

Issuance rules or modalities would be key to ensuring a stable value. Rules would be unlikely to achieve adequate fine-tuning of global liquidity provision, given the complexity of the task. Discretion would give the governing body of the IMI power of such importance as to warrant a governance structure similar to that of an independent central bank, melding accountability and representativeness with political independence and expertise. This body would also be responsible for determining the composition of the IMI's assets, i.e., how to maintain a mix of country assets to minimize balance sheet risks.

This proposal—assuming a strong and well-allocated balance sheet of the IMI—would achieve most of the desirable properties of an international monetary system - including efficiency and symmetry of adjustment, maximal scale economies, and eliminate exorbitant privilege for any country (see Figure 2). Key implementation issues to be addressed include: political coordination to set up the IMI and agree on its governance arrangements (a high degree of political independence would be required); economic decisions on the size and composition of its balance sheet; and measures needed to jumpstart network effects (similar to those discussed for ensuring the liquidity of the SDR).

The credibility of the IMI and the stable value of the GRC depend not only on appropriate implementation of the above but also a track record of sound judgment by the IMI board. In this regard, many of the problems of ordinary monetary policy would also arise here, such as potentially long lags in the effects of decisions and possible destabilizing impacts on exchange rates.

\footnotetext{
1/ See United Nations (2009) for a similar proposal of a new global reserve system.
} 


\section{Conclusion}

24. Making the best of the current system. The current system has its flaws, including occasionally bouts of serious instability, but it also has proved its strength and resilience when the conceivable alternatives have not. As the pressure points in current arrangements are better understood, so the remedies become clearer - a more stable center, stronger policy frameworks in the periphery countries, and of course less volatile capital flows. These remedies must be pursued, but counting on them alone to achieve lasting stability would be assuming the problem away.

25. Charting the road ahead. The ideas discussed in this paper-toward better insurance and a gradual widening of the reserve asset menu - aim to help policy makers think beyond the status quo in fundamental ways. Rather than rapid, far-reaching change with unpredictable consequences, the key in the period ahead will be to agree on a set of initiatives that will nudge the system toward lasting stability. In this spirit, serious consideration should be given to the proposed avenues to provide alternatives to selfinsurance, and to the potential — both practical and political — for other currencies to acquire a greater role in the global reserve system. Such work could help the system evolve to shape developments rather than the other way around, as has tended to be the norm historically. 
Figure 2. Features of Alternative International Monetary and Reserve Systems

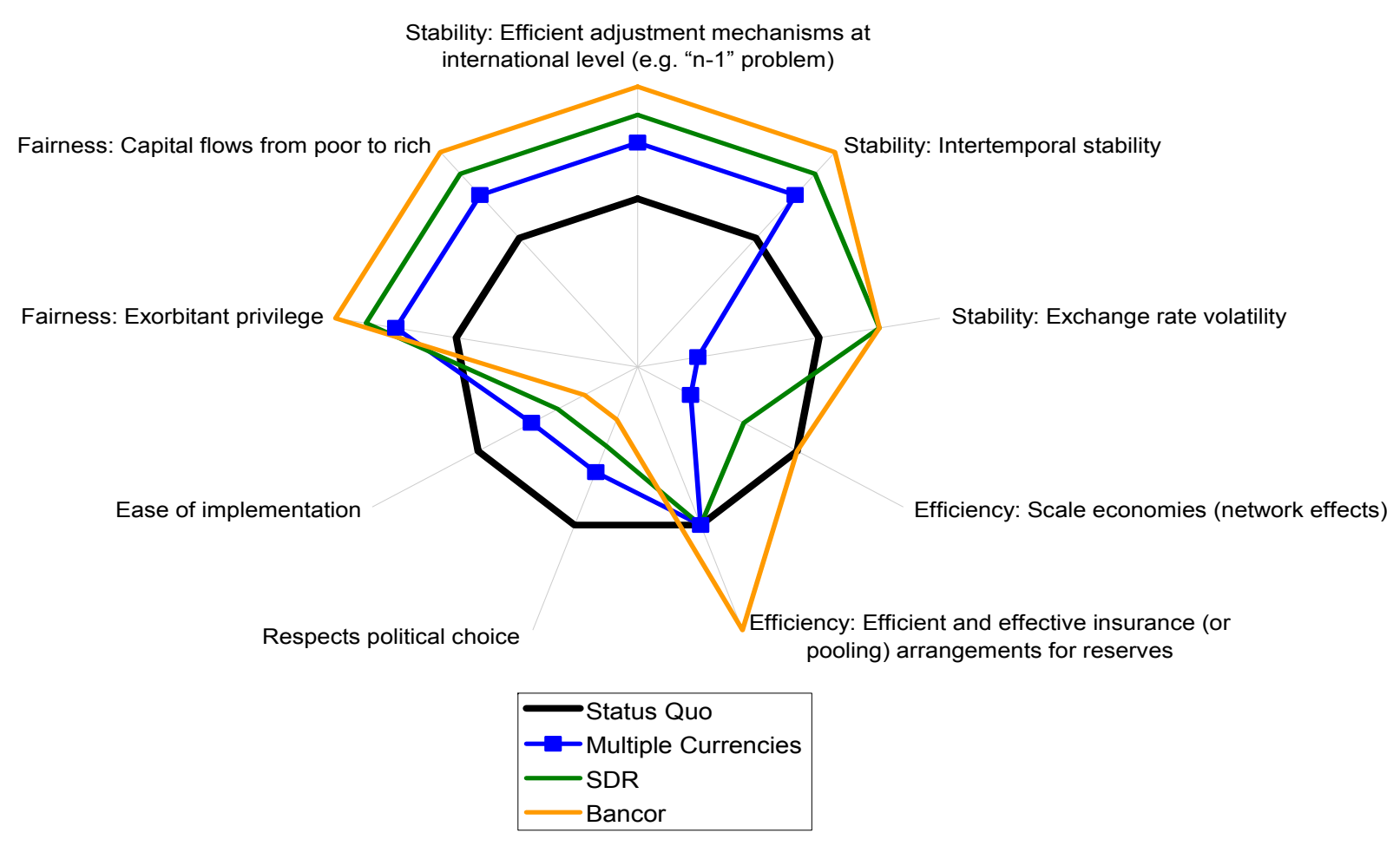




\section{Bibliography}

Bergsten, C.F., 2009, “We Should Listen to Beijing's Currency Idea," Financial Times op-ed. Available via the Internet at http://www.iie.com/publications/opeds/oped.cfm?ResearchID=1180.

Blanchard, O., and G.M. Milesi-Ferretti, 2009, "Global Imbalances: Past, Present, and Future," IMF, forthcoming.

Calvo, G., 2009, "Lender of Last Resort: Put It on the Agenda! - Commentary." Available via the Internet at $\mathrm{http}: / /$ www.voxeu.org/index.php?q=node/3327.

Clarida, R., 2009, "With Privilege Comes...?" Available via the Internet at http://www.pimco.com/LeftNav/Global+Markets/Global+Perspectives/2009/With+Privil ege+Comes+Clarida+Oct+2009.htm\#).

Clark, P., and J. Polak, 2004, "International Liquidity and the Role of the SDR in the International System," IMF Staff Papers, Vol. 51 (April), pp. 47-71.

Cohen, D., and R. Portes, 2006, “Toward a Lender of First Resort,” IMF Working Paper 06/66 (Washington: International Monetary Fund).

Cooper, R., 2009, "Necessary Reform? The IMF and International Financial Architecture," Harvard International Review, Vol. 30, Vol. 4, pp. 52-55.

Cordella, T., and E. Levy-Yeyati, 2006, "The Case for an IMF Insurance Facility," in Reforming the IMF for the 21st Century, ed. by T. Truman (Washington: Petersen Institute for International Economics).

Eichengreen, B., 2009, "Out of the Box Thoughts About the International Financial Architecture,” IMF Working Paper 09/116 (Washington: International Monetary Fund).

Heller, H.R., 1966, “Optimal International Reserves,” Economic Journal, Vol. 76 (June), pp. 296-311.

Hviding, K., M. Nowak, and L.A. Ricci, 2004, "Can Higher Reserves Help Reduce Exchange Rate Volatility?” IMF Working Paper 04/189 (Washington: International Monetary Fund).

Jeanne, O., and R. Ranciere, 2006, "The Optimal Level of International Reserves for Emerging Market Countries,” IMF Working Paper 06/229 (Washington: International Monetary Fund).

Johnson, S., 2008, "Shadow Agenda for the G-20 Summit: More Money for the IMF." Available via the Internet at http://www.petersoninstitute.org/realtime/?p=222. 
Meissner, C., and N. Oomes, 2008, "Why Do Countries Peg the Way They Peg? The Determinants of Anchor Currency Choice," IMF Working Paper 08/132 (Washington: International Monetary Fund).

Obstfeld, M., J. Shambaugh, and A.M. Taylor, 2009, "Financial Stability, the Trilemma, and International Reserves," American Economic Journal, forthcoming.

Ocampo, J.A., 2009, "Special Drawing Rights and the Reform of the Global Reserve System," for the Intergovernmental Group of Twenty-Four. Available via the Internet at www.g24.org/jao0909.pdf.

Ostry, J., and J. Zettelmeyer, 2005, "Strengthening IMF Crisis Prevention," IMF Working Paper 05/206 (Washington: International Monetary Fund).

Stern, N., 2009, "The World Needs an Unbiased Risk Assessor," Financial Times op-ed. Available via the Internet at http://www.ft.com/cms/s/0/4dbf6ae2-1894-11de-bec8$\underline{0000779 f d 2 a c . h t m l}$.

Subramanian, A., 2009, "China and the Dollar: Having It Both Ways." Available via the Internet at http://www.voxeu.org/index.php?q=node/3350.

United Nations, 2009, Report of the Commission of Experts of the President of the United Nations General Assembly on Reforms of the International Monetary and Financial System (also known as the Stiglitz Commission report). Available via the Internet at http://www.un.org/ga/econcrisissummit/docs/FinalReport CoE.pdf.

Zhou, X., 2009, "Reform the International Monetary System" (Beijing: People's Bank of China). Available via the Internet at http://www.china.org.cn/business/news/200903/24/content_17490662.htm. 